\title{
Effect of lipopolysaccharide on angiotensin II type 1 receptor expression and function in human pulmonary microvascular endothelial cells
}

\author{
HONG-PENG LI $^{1,2}$, HAI-BO QIU ${ }^{1}$ and HAI-QIN WANG ${ }^{3}$ \\ ${ }^{1}$ Department of Critical Care Medicine, Zhongda Hospital Affiliated to Southeast University, Nanjing, Jiangsu 210009; \\ ${ }^{2}$ Department of Critical Care Medicine, Yuncheng Central Hospital, Yuncheng, Shanxi 044000; \\ ${ }^{3}$ Department of Health Service Management, School of Public Health, Fudan University, \\ Shanghai 200433, P.R. China
}

Received October 15, 2014; Accepted August 17, 2015

DOI: $10.3892 / \mathrm{mmr} .2015 .4481$

\begin{abstract}
Lipopolysaccharides (LPSs) are an important initiation factor in acute respiratory distress syndrome. The aim of the present study was to investigate the effect of LPSs on the regulation of angiotensin II (Ang II) receptors in human pulmonary microvascular endothelial cells (HPMECs). HPMECs were treated with $0,50,100$ or $200 \mathrm{ng} / \mathrm{ml}$ LPS and incubated for 4, 8, 12 or $16 \mathrm{~h}$. The expression of Ang II type 1 receptor (AT1R) and Ang II type 2 receptor (AT2R) was determined using reverse transcription-polymerase chain reaction and western blot analysis. The affinity to Ang II was measured using a radioligand binding assay. No AT2R expression was detected with or without LPS administration in HPMECs, and LPS treatment increased the expression level of AT1R. A time-dependent increase of AT1R transcription was observed in the $50 \mathrm{ng} / \mathrm{ml}$ group, while in the 100 and $200 \mathrm{ng} / \mathrm{ml}$ groups, the AT1R mRNA levels reached peak values at $4 \mathrm{~h}$ and remained unchanged. The protein level of AT1R increased significantly in a dose-dependent manner for each incubation time period. A time-dependent increase in the protein level was observed in the 50 and $100 \mathrm{ng} / \mathrm{ml}$ groups. As for the $200 \mathrm{ng} / \mathrm{ml}$ group, the level of AT1R reached a peak value at $8 \mathrm{~h}$. Maximal binding (Bmax) significantly increased following LPS treatment and Bmax of the $50 \mathrm{ng} / \mathrm{ml}$ group exhibited a time-dependent increase. The Bmax of
\end{abstract}

Correspondence to: Dr Hong-Peng Li, Department of Critical Care Medicine, Yuncheng Central Hospital, 3690 Hedong East Street, Yuncheng, Shanxi 044000, P.R. China

E-mail: liroc119@163.com

Dr Hai-Bo Qiu, Department of Critical Care Medicine, Zhongda Hospital Affiliated to Southeast University, 87 Dingjiaqiao, Nanjing, Jiangsu 210009, P.R. China

E-mail: haiboq2000@yahoo.com.cn

Key words: angiotensin II, angiotensin II receptors, acute respiratory distress syndrome, acute lung injury, lipopolysaccharide the 100 and $200 \mathrm{ng} / \mathrm{ml}$ groups reached peak values at 12 and $8 \mathrm{~h}$, respectively, and decreased thereafter. The dissociation constant remained unchanged following LPS treatment. Thus, treatment with LPS increased AT1R expression and its Bmax to Ang II in HPMECs, however, did not alter the affinity of AT1R to Ang II.

\section{Introduction}

Angiotensin II (Ang II) is a major effector peptide of the renin-angiotensin system (RAS), which controls blood pressure and the blood volume of the cardiovascular system $(1,2)$. Previous studies demonstrated that Ang II is involved in key events in the regulation of various types of inflammatory mediator $(3,4)$. The effect of Ang II is mediated by two $\mathrm{G}$ protein-coupled receptors, Ang II type 1 receptor (AT1R) and Ang II type 2 receptor (AT2R), which competitively bind to Ang II. AT1R stimulates protein phosphorylation, while AT2R stimulates protein dephosphorylation, which counterbalances the effects of protein kinases, particularly mitogen-activated protein kinases. The expression of AT1R and AT2R vary in states of injury, ischemia and inflammation and differ among tissues and organs $(5,6)$. A switch in binding to AT1R or AT2R affects the physiological and pathological functions of Ang II (7).

Evidence suggests that RAS is critical in acute lung injury (ALI) and acute respiratory distress syndrome (ARDS) $(5,8,9)$. In the development of ARDS, the RAS is activated, leading to a significant increase in levels of Ang II in the bronchoalveolar lavage fluid and aggravating the lung inflammatory response (9). In addition, lipopolysaccharides (LPS) are considered to be important initiation factors for ARDS. LPSs increase pulmonary endothelial permeability, which results in pulmonary edema and ALI $(10,11)$. In addition, a previous study revealed that LPS upregulated the expression of AT1R in rat pulmonary microvascular endothelial cells (PMECs) (12); however, verification in human cells remained to be elucidated. To further examine this area, the regulation of LPS on Ang II receptors in human PMECs (HPMECs) was investigated in the present study. 


\section{Materials and methods}

Reagents. LPS from Escherichia coli 0111:B4 and synthetic Ang II were purchased from Sigma-Aldrich (St. Louis, MO, USA). ${ }^{125}$ I-labeled Ang II ( ${ }^{125} \mathrm{I}-\mathrm{Ang} \mathrm{II} ; 200-300 \mathrm{Ci} / \mathrm{mmol}$ ) was purchased from Beijing FuRui Biotech Company (Beijing, China). The mouse anti-human AT1R monoclonal antibodies (cat. no. 214988) and goat anti-mouse immunoglobulin (Ig)G/horseradish peroxidase (HRP) (cat. no. FI120611) were purchased from Abcam (Cambridge, MA, USA). The AccessQuick RT-PCR system (Promega-A1702)was purchased from Promega Corp. (Madison, WI, USA). HPMECs (cat. no. 3000), endothelial cell medium (ECM) and endothelial cell growth supplement (ECGS) were obtained from ScienCell Research Laboratories (Carlsbad, CA, USA). Finally, human renal mesangial cells (HRMCs) were purchased from the Cardiovascular Institute of Southeast University (Nanjing, China).

Immunofluorescence. HPMECs and HRMCs were identified as endothelial cells by morphology and were characterized by immunofluorescence with the following antibodies: Mouse anti-human vWF IgG/fluorescein isothiocyanate (FITC; cat. no. sc-365712), mouse anti-human desmin IgG/FITC (cat. no.sc-271677; Santa Cruz Biotechnology,Inc.,Dallas, TX, USA), mouse anti-human CD31 IgG/FITC (cat. no. BYK-0468R) and mouse anti-human cytokeratin IgG/FITC (cat. no. BYK-1712R; Boye Biotech Co., Ltd., Zhenjing, China). The cells of passage 6 were used for identification. Monolayers of cells were grown to confluence on gelatin-coated glass coverslips. The coverlips were then washed twice with phosphate-buffered saline (PBS; Shenneng Bocai Biotechnology Co., Ltd., Shanghai, China), fixed in acetone at $4^{\circ} \mathrm{C}$ and allowed to air dry. Subsequently, the cells were stained with the antibodies (anti-vWF-FITC, anti-desmin-FITC, anti-cytokeratin-FITC and anti-CD31FITC; 1:1,000 dilution), respectively, on ice for $20 \mathrm{~min}$ in the dark. Subsequently, cells were washed three times with PBS. The detected cells were viewed under a fluorescence microscope (L2001A; Boshida Optical Instrument Co., Ltd, Shenzhen, China).

Cell culture and intervention. The culture of HPMECs was performed according to a modified version of a previously described method (13). Briefly, the frozen HPMECs were thawed, and inoculated at a density of $5,000 \mathrm{cells} / \mathrm{cm}^{2}$ into a T-25 flask (Sigma-Aldrich) containing $5 \mathrm{ml} \mathrm{ECM} \mathrm{with} 1 \%$ ECGS, penicillin $(60 \mu \mathrm{g} / \mathrm{ml})$, streptomycin $(100 \mu \mathrm{g} / \mathrm{ml})$ and $5 \%$ fetal bovine serum (all from ScienCell Research Laboratories) at $37^{\circ} \mathrm{C}$. The HPMECs were subsequently placed in an incubator under a $5 \% \mathrm{CO}_{2}$ humidified atmosphere. Passages 6-7 were used for experimentation. LPS at varying concentrations $(0,50,100$ or $200 \mathrm{ng} / \mathrm{ml})$ was added and the cells were incubated for $4,8,12$ or $16 \mathrm{~h}$.

Semi-quantitative reverse transcription-polymerase chain reaction (RT-PCR) assay. Total RNA was extracted from the HPMECs using the RT system according to the manufacturer's instructions. RT-PCR was performed with an AccessQuick RT-PCR system (Promega Corp.) according to the manufacturer's instructions. The primer sequences were designed and synthesized by (Sangon Biotech, Shanghai, China) with sequences as follows: Forward, 5'-CCAGCTATAATCCAT CGAAA-3' and reverse, 5'-TGAATATTTGTGGGGAATC-3' for ATIR; forward, 5'-CTGCTGTTGTTCTGGCCTTCA-3' and reverse, 5'-CTCTCTCTTTTCCCTTGGAGTT-3' for $A T 2 R$. GAPDH was co-amplified as an internal control using the following primer sequences: Forward, 5'-CTTCATTGA CCTAACTACATGG-3' and reverse, 5'-GAGGGGCCATCC ACAGTCTTCTG-3' for GAPDH. The designed primers were confirmed using HRMCs as a positive control into which ATIR and $A T 2 R$ were transcribed (data not shown). Thermocycling conditions were as follows: $94^{\circ} \mathrm{C}(2 \mathrm{~min})$ followed by $94^{\circ} \mathrm{C}$ $(30 \mathrm{sec}), 57^{\circ} \mathrm{C}(1 \mathrm{~min})$ and $68^{\circ} \mathrm{C}(2 \mathrm{~min})$ for 32 cycles, and $7 \mathrm{~min}$ at $72^{\circ} \mathrm{C}$. The PCR products were stored at $-20^{\circ} \mathrm{C}$ prior to quantification by electrophoresis on agarose gels (Shenneng Bocai Biotechnology Co., Ltd.), which were scanned and analyzed using Gel Scan2XL system (Shimadzu, Kyoto, Japan) for semi-quantitative evaluation. Quantity and quality of the included RNA were controlled by an additional PCR from the same reverse-transcription samples using GAPDH as an internal standard. The PCR products were electrophoresed on agarose gels.

Western blotting. The cells were harvested, lysed in chilled cell lysis buffer (radioimmunoprecipitation assay buffer; Shenneng Bocai Biotechnology Co., Ltd.) at a density of $10^{6}$ cells $/ 500 \mu \mathrm{l}$ for $10 \mathrm{~min}$ and centrifuged at $15,000 \mathrm{x} \mathrm{g}$ at $4^{\circ} \mathrm{C}$ for $15 \mathrm{~min}$. The precipitate was recovered and stored in aliquots at $-80^{\circ} \mathrm{C}$. The protein concentration of samples was estimated using ultraviolet spectrophotometry (BioSpectrometer; Eppendorf, Hamburg, Germany). Immunoblotting was performed as previously described (14). Briefly, the protein samples were electrophoresed and the gels were transferred onto polyvinylidene difluoride membranes (Shimadzu, Kyoto, Japan) prior to blocking for $2 \mathrm{~h}$ with 5\% bovine serum albumin (BSA) and $0.05 \%$ Tween-20 in PBS (all from Shenneng Bocai Biotechnology Co., Ltd.). Subsequently, the samples were incubated with mouse anti-human AT1R or AT2R monoclonal antibodies $(1: 2,500 ; 8 \mu \mathrm{g} / \mathrm{ml})$ in $5 \%$ BSA overnight at $4^{\circ} \mathrm{C}$. The blot was washed three times with PBS and then incubated with HRP-linked goat anti-mouse IgG at 1:2,500 in PBS for $1 \mathrm{~h}$. After the blot was washed three times with PBS, antibodies were visualized using an enhanced chemiluminescence kit (Cell Signaling Technology company, Danvers, MA, USA) and signals were recorded as bands on Kodak X-ray films (Eastman-Kodak, Rochester, NY, USA). The film was scanned and the band intensity was analyzed using a densitometer (MSF-300 G Scanner; Microtek, Xinzhu, Taiwan). $\beta$-actin served as an internal reference.

Radioligand binding assay (RLBA). An RLBA was performed as previously described (15). Briefly, the cells were inoculated in 24-well plates at a density of $5 \times 10^{4}$ cells/well using the medium described above. LPS at varying concentrations $(0,50,100$ or $200 \mathrm{ng} / \mathrm{ml})$ was added. The cells were incubated for $4,8,12$ or $16 \mathrm{~h}$ and subsequently kept in chilled PBS for $10 \mathrm{~min}$. The cells were washed again using $2 \mathrm{ml}$ chilled PBS to remove endogenous AngII completely. According to protocols of previous studies $(16,17)$, the cells were incubated with $0.5 \mathrm{ml}$ binding medium containing various doses of ${ }^{125} \mathrm{I}$-Ang II 


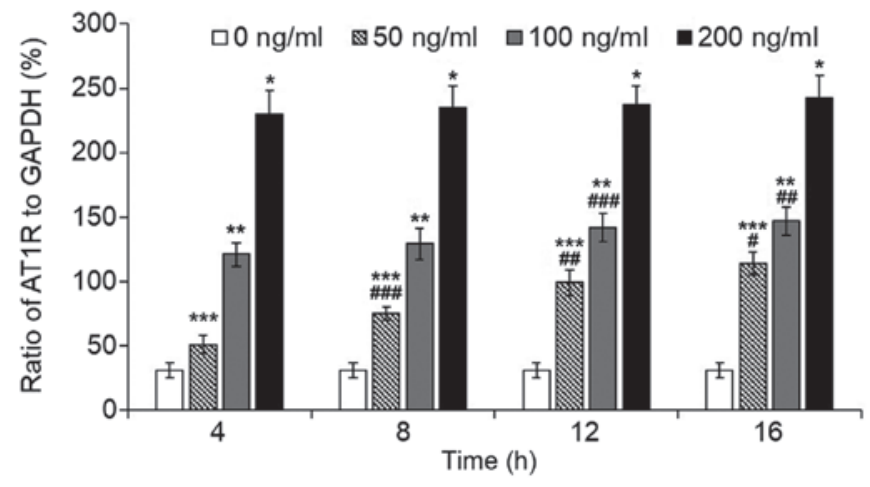

Figure 1. Effect of lipopolysaccharide on AT1R transcription in human pulmonary microvascular endothelial cells. Error bars indicate the standard deviation. For the same incubation time, ${ }^{*} \mathrm{P}<0.05$ vs the 0,50 and $100 \mathrm{ng} / \mathrm{ml}$ groups; ${ }^{* * *} \mathrm{P}<0.05$ vs the 0 and $50 \mathrm{ng} / \mathrm{ml}$ groups; ${ }^{* * * *} \mathrm{P}<0.05$ vs the $0 \mathrm{ng} / \mathrm{ml}$ group. For the same concentration, ${ }^{\#} \mathrm{P}<0.05$ vs the 4,8 and $12 \mathrm{~h}$ groups; ${ }^{\#} \mathrm{P}<0.05$ vs. the 4 and 8 h groups; ${ }^{\# \#} \mathrm{P}<0.05$ vs the $4 \mathrm{~h}$ group. AT1R, angiotensin II type 1 receptor.

A

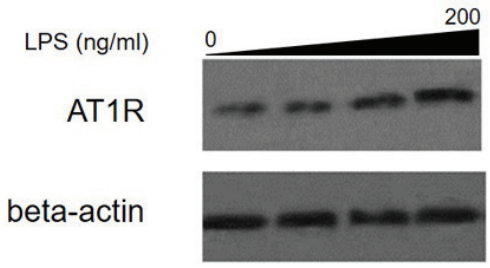

$4 \mathrm{~h}$

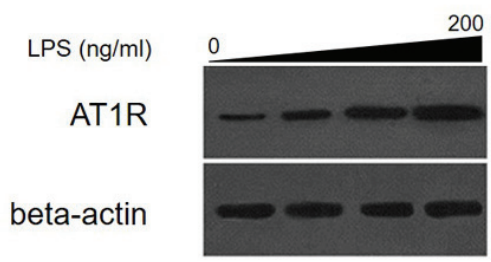

$12 \mathrm{~h}$

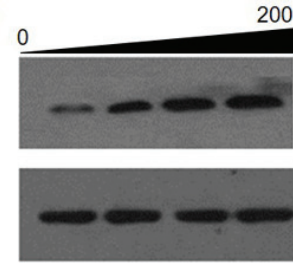

$8 \mathrm{~h}$

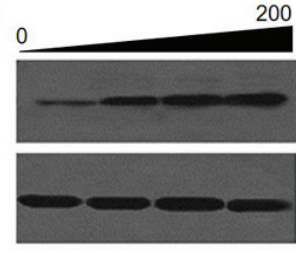

$16 \mathrm{~h}$

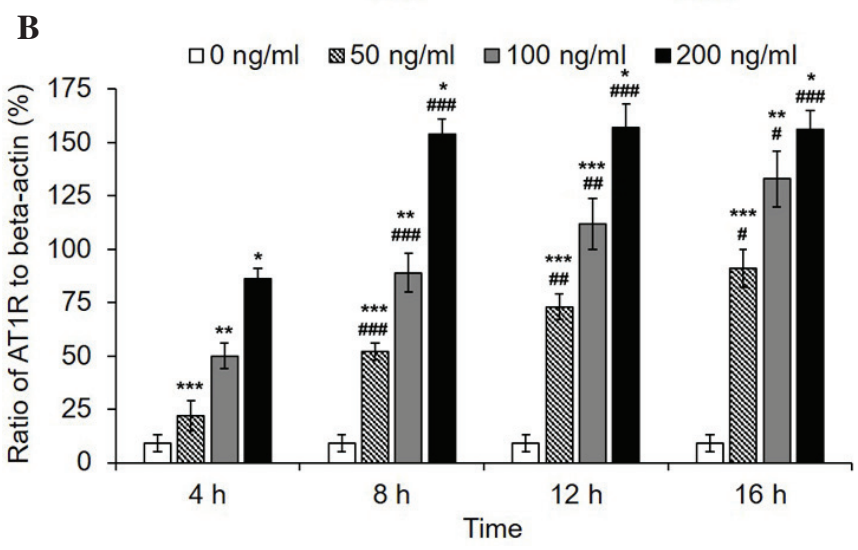

Figure 2. Effect of LPS on AT1R translation in HPMECs. (A) Representative western blot analysis revealed the expression of AT1R protein in HPMECs following LPS treatment. (B) Bar chart indicating LPS-induced upregulation of AT1R translation. Error bars indicate the standard deviation. For the same incubation time, ${ }^{*} \mathrm{P}<0.05$ vs. the 0,50 and $100 \mathrm{ng} / \mathrm{ml}$ groups; ${ }^{* *} \mathrm{P}<0.05$ vs. the 0 and $50 \mathrm{ng} / \mathrm{ml}$ groups; ${ }^{* * *} \mathrm{P}<0.05 \mathrm{vs}$. the $0 \mathrm{ng} / \mathrm{ml}$ group. For the same concentration, ${ }^{\#} \mathrm{P}<0.05$ vs. the 4,8 and $12 \mathrm{~h}$ groups; ${ }^{\# \#} \mathrm{P}<0.05$ vs. the 4 and $8 \mathrm{~h}$ groups

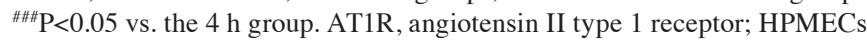
human pulmonary microvascular endothelial cells; LPS, lipopolysaccharide.

$(0.1,0.2,0.4,0.8,1.6$ or $2.0 \mathrm{fmol} /$ well $)$. Nonspecific binding (NSB) was evaluated in the presence of $5 \mu \mathrm{g}$ unlabeled Ang II
$(10 \mu \mathrm{g} / \mathrm{ml})$ at which AT1R was entirely saturated. The medium was removed following incubation at $4^{\circ} \mathrm{C}$ for $2 \mathrm{~h}$, and the cells were washed three times with PBS and transferred to a $0.25 \mathrm{~mol} / 1 \mathrm{NaOH}-0.05 \%$ SDS lysis buffer (Shenneng Bocai Biotechnology Co., Ltd.). The radioactivity was measured using a $\gamma$-counter system (GC-911; ZhongJia photoelectricity, Hefei, China). Data on the total binding (TB) and total ligand (LT) were obtained. Specific binding (B) and free ligand (F) were calculated as follows: $\mathrm{B}=\mathrm{TB}-\mathrm{NSB}$ and $\mathrm{F}=\mathrm{LT}-\mathrm{TB}$. The maximal binding (Bmax) and dissociation constant $(K \mathrm{~d})$ were determined by Scatchard plot analysis according to the equation: $\mathrm{B} / \mathrm{F}=-\mathrm{B} / K \mathrm{~d}+\mathrm{B} \max / K \mathrm{~d}$.

Statistical analysis. Data are expressed as the mean \pm standard deviation. SPSS version 18.0 (SPSS Inc., Chicago, IL, USA) was used for statistical analyses. Differences between groups were examined using one-way analysis of variance. Dunnett's test was used for post hoc analysis and $\mathrm{P}<0.05$ was considered to indicate a statistically significant difference.

\section{Results}

HPMECs and HRMCs characteristics. HPMECs presented with a cobblestone morphology and were characterized by vWF and CD31 antigen expression as revealed by immunofluorescence (data not shown). HRMCs exhibited a stellate or spindle-like morphology, expressed desmin antigen, and did not express vWF, CD31 or cytokeratin antigen, as indicated by immunofluorescence.

LPS increases AT1R expression in HPMECs. The transcription of $A T 1 R$ increased significantly following LPS treatment (Fig. 1). After a 16-h incubation, LPS caused an increase of $\sim 8$-fold in the $200 \mathrm{ng} / \mathrm{ml}$ group, and $\sim 5$-fold increase in the $100 \mathrm{ng} / \mathrm{ml}$ group. In the $50 \mathrm{ng} / \mathrm{ml}$ group, the increase of ATIR transcription exhibited a significant time-dependent effect, whereas in the 100 and $200 \mathrm{ng} / \mathrm{ml}$ groups, ATIR transcription appeared to be stably maintained following a 4-h incubation with the exception of a marginal increase after an 8-h incubation in the $100 \mathrm{ng} / \mathrm{ml}$ group ( 16 vs. $4 \mathrm{~h}, \mathrm{P}=0.001 ; 16$ vs. 8 h, $\mathrm{P}=0.018 ; 12$ vs. 4 h, $\mathrm{P}=0.011$ ). Consistently, western blot analysis revealed a marked increase in the AT1R protein level following LPS treatment (Fig. 2). A significant dose-dependent increase was observed in each group for each incubation duration. A time-dependent increase was observed in the 50 and $100 \mathrm{ng} / \mathrm{ml}$ groups, while in the $200 \mathrm{ng} / \mathrm{ml}$ group, AT1R quantities reached a peak value after an 8 -h incubation then remained at the same level. Transcription of $A T 2 R$ was not detected in the HPMECs with or without LPS; however, a fault with the primers was excluded, as the primers had been used effectively in the HRMCs in which $A T 2 R$ was transcribed (Data not shown). In addition, western blot analysis revealed that AT2R was not expressed.

LPS increases Bmax, but not the affinity of HPMEC-expressed AT1R to Ang II. The Bmax of AT1R of the treated groups (50, 100 and $200 \mathrm{ng} / \mathrm{ml}$ ) increased significantly compared with the control group (Fig. 3). Scatchard plotting revealed a significant linear correlation and regression $\left(\mathrm{R}^{2}=0.9514, \mathrm{~b}=-0.00092\right)$. The Bmax of the 100 and $200 \mathrm{ng} / \mathrm{ml}$ groups reached a peak 
Table I. Dissociation constant of each group at varying lipopolysaccharide concentrations ( $\mathrm{ng} / \mathrm{ml})$.

Dissociation constant (pmol/l)

\begin{tabular}{ccccc}
\cline { 2 - 5 } Time (h) & $0 \mathrm{ng} / \mathrm{ml}$ & $50 \mathrm{ng} / \mathrm{ml}$ & $100 \mathrm{ng} / \mathrm{ml}$ & $200 \mathrm{ng} / \mathrm{ml}$ \\
\hline 4 & $111 \pm 5$ & $106 \pm 7$ & $100 \pm 7$ & $109 \pm 6$ \\
8 & $111 \pm 5$ & $117 \pm 9$ & $111 \pm 12$ & $111 \pm 6$ \\
12 & $111 \pm 5$ & $113 \pm 11$ & $112 \pm 9$ & $114 \pm 8$ \\
16 & $111 \pm 5$ & $111 \pm 12$ & $116 \pm 10$ & $120 \pm 9$
\end{tabular}

Data are expressed as the mean \pm standard deviation $(\mathrm{P}>0.05)$.
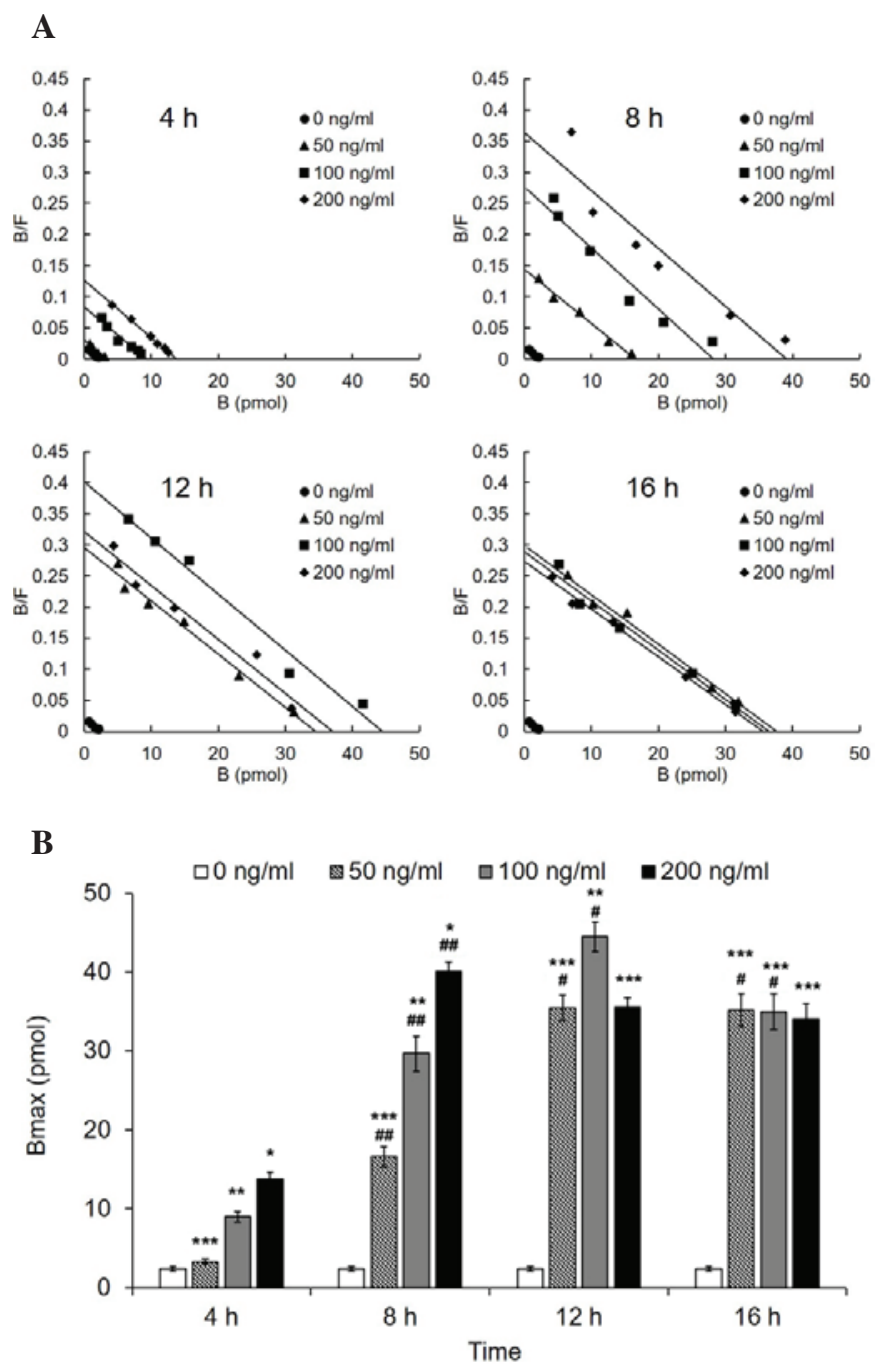

Figure 3. Effects of LPS on vascular AT1R binding. (A) Scatchard analysis of the AT1R binding in cells treated with LPS. (B) Bmax of AT1R in cells treated with LPS. Error bars indicate the standard deviation. For the same incubation time, ${ }^{*} \mathrm{P}<0.05$ vs. the 0,50 and $100 \mathrm{ng} / \mathrm{ml}$ groups; ${ }^{* *} \mathrm{P}<0.05$ vs. the 0 and $50 \mathrm{ng} / \mathrm{ml}$ groups; ${ }^{* * * *} \mathrm{P}<0.05$ vs. the $0 \mathrm{ng} / \mathrm{ml}$ group. For the same concentration, ${ }^{*} \mathrm{P}<0.05$ vs. the 4 and $8 \mathrm{~h}$ groups; ${ }^{\# /} \mathrm{P}<0.05$ vs. the $4 \mathrm{~h}$ group. AT1R, angiotensin II type 1 receptor; LPS, lipopolysaccharide; Bmax, maximal binding.

value at 12 and $8 \mathrm{~h}$, respectively, and the two exhibited a significant decrease thereafter significant decrease thereafter
(12 vs. $16 \mathrm{~h}$ in the $100 \mathrm{ng} / \mathrm{ml}$ group, $\mathrm{P}<0.001 ; 8$ vs. $12 \mathrm{~h}$ and 8 vs. $16 \mathrm{~h}$ in the $100 \mathrm{ng} / \mathrm{ml}$ group, $\mathrm{P}<0.001)$. By contrast, the Bmax of the $50 \mathrm{ng} / \mathrm{ml}$ group increased to the peak value at $12 \mathrm{~h}$ in a time-dependent manner, and remained unchanged at $16 \mathrm{~h}$. In addition, the Bmax did not differ among the three treated groups at the $16 \mathrm{~h}$ time point. Correspondingly, the $K \mathrm{~d}$ representing the affinity exhibited no difference in all of the groups (Table I).

\section{Discussion}

The present study demonstrated that only AT1R was expressed in HPMECs. LPS increased AT1R expression levels, however, did not activate AT2R expression. The result is consistent with a previous study performed using rat pulmonary microvascular endothelial cells (12). Notably, LPS increased the Bmax of AT1R to Ang II. In addition, the effects of LPS concentration and incubation time on the expression and affinity of AT1R to Ang II were compared.

In the development of ARDS, the endothelial cells act as a barrier to pre-inflammatory mediators and are critical in regulating the exudation of proteins and fluid, vascular tone, hemostasis and inflammatory cells. Ang II activation in HPMECs is important in the pathophysiology of ARDS. Ang II mediates inflammation via AT1R and previous evidence indicates that AT1R is upregulated under certain types of pathological stimulation, i.e. by inflammatory factors. Previous studies have identified that tumor necrosis factor- $\alpha$, interleukin-1, and interferon- $\gamma$ upregulate AT1R expression levels in cardiac fibroblasts and vascular smooth muscle cells $(8,18,19)$. The increase of AT1R expression is associated with inflammation and other pathological effects. Furthermore, the change in AT1R expression is important in the inflammatory response in the lungs, which may involve the onset and progression of ARDS. In addition, it has been reported that AT1R blockers delay the onset of ARDS (20).

The results of the present study demonstrate that LPS enhances the expression of AT1R in HPMECs with an increased stimulating concentration of LPS and a longer time duration. Notably, it was observed that AT1R expression increased in a time-dependent manner in the low concentration groups, whereas in the $200 \mathrm{ng} / \mathrm{ml}$ group, the expression appeared to reach a peak value within a short incubation time. It was therefore hypothesized that increasing the LPS concentration increased the rate of AT1R expression. The increase in expression level in the high concentration groups was particularly rapid, therefore the process was not captured. The level of AT1R expression reached different peak values in the three groups within the examined time course. Thus, it was proposed that peak value may be associated with LPS concentration. In addition, HPMECs did not express AT2R and treatment with LPS failed to activate AT2R. Therefore, the physiological role of AT2R remains to be clarified. It is hypothesized that the LPS-regulation of AT2R may be tissue-specific and AT2R may not be involved in ARDS.

The mechanism that mediates the LPS-induced increase of AT1R expression in HPMECs remains to be elucidated. Studies have indicated that nuclear factor (NF)- $\mathrm{kB}$ is required for cytokine-induced upregulation of AT1R transcription in rat cardiac fibroblasts (21). Preliminary bioinformatic analysis of 
the 5'-flanking region of $A T 1 R$ revealed two putative $\mathrm{NF}-\kappa \mathrm{B}$ binding sites at positions -365 and -2540 (22). LPS, a strong pre-inflammatory factor, potently activate NF- $\kappa \mathrm{B}$ through a toll-like receptor (23). It was hypothesized that $\mathrm{NF}-\kappa \mathrm{B}$ may also be involved in the LPS-induced upregulation of AT1R transcription in HPMECs, which requires examination in future studies.

AT1R functions upon binding to Ang II. Therefore, the affinity and binding capacity of the highly-expressed AT1R was assessed. It was confirmed by RLBA that LPS-induced AT1R binding escalated with treatment durations between 4 and $16 \mathrm{~h}$ in the $50 \mathrm{ng} / \mathrm{ml}$ group. The increased Bmax may have been due to the upregulation of AT1R expression. Increased binding of AT1R to Ang II may be involved in the development of ARDS. However, an explanation for the decrease in binding after $12 \mathrm{~h}$ and after $8 \mathrm{~h}$ in the 100 and $200 \mathrm{ng} / \mathrm{ml}$ groups, respectively, remains to be elucidated. The complex mechanism of Ang II binding-induced AT1R internalization may be a possible explanation; AT1R has long been considered as an internalizing receptor (24). Internalization of Ang II has been reported in numerous cells of vascular, adrenal and renal origin, which express AT1R. The majority of the morphological data indicate that endocytosis of AT1R occurs via coated endocytic vesicles, similar to the internalization mechanism of the majority of other $\mathrm{G}$ protein-coupled receptors (25). Thus, internalization may also be associated with the LPS concentration, as the Bmax of the 100 and $200 \mathrm{ng} / \mathrm{ml}$ groups dropped more markedly than that of the $50 \mathrm{ng} / \mathrm{ml}$ group.

In addition, alteration of the affinity of Ang II binding to AT1R may alter AT1R pre-inflammatory function. In the RLBA experiment, the sole function of the cells is the specific binding with their associated ligand. The critical factor affecting the affinity is the phosphorylation of the receptor's intracellular domain. The present RLBA experiment demonstrated that LPS failed to alter the affinity of Ang II binding to AT1R.

In conclusion, LPS enhanced AT1R expression, although did not activate AT2R expression in HPMECs. In addition, LPS increased the binding of AT1R to Ang II, however did not alter the affinity of AT1R to Ang II. The present results indicate that AT1R may be involved in LPS-induced ARDS.

\section{Acknowledgements}

The present study was supported by the National Natural Science Foundation of China (grant no. 30640012).

\section{References}

1. Li JS, Touyz RM and Schiffrin EL: Effects of AT1 and AT2 angiotensin receptor antagonists in angiotensin II-infused rats. Hypertension 31: 487-492, 1998.

2. Griendling KK and Ushio-Fukai M: Reactive oxygen species as mediators of angiotensin II signaling. Regul Pept 91: 21-27, 2000

3. Zhang H, Schmeisser A, Garlichs CD, Plötze K, Damme U, Mügge A and Daniel WG: Angiotensin II-induced superoxide anion generation in human vascular endothelial cells: Role of membrane-bound NADH-/NADPH-oxidases. Cardiovasc Res 44: 215-222, 1999.

4. Ruiz-Ortega M, Lorenzo O, Ruperez M, König S, Wittig B and Egido J: Angiotensin II activates nuclear transcription factor kappaB through AT(1) and AT(2) in vascular smooth muscle cells: Molecular mechanisms. Circ Res 86: 1266-1272, 2000.
5. Marshall RP, Gohlke P, Chambers RC, Howell DC, Bottoms SE, Unger T, McAnulty RJ and Laurent GJ: Angiotensin II and the fibroproliferative response to acute lung injury. Am J Physiol Lung Cell Mol Physiol 286: L156-L164, 2004.

6. Marshall RP, McAnulty RJ and Laurent GJ: Angiotensin II is mitogenic for human lung fibroblasts via activation of the type 1 receptor. Am J Respir Crit Care Med 161: 1999-2004, 2000.

7. Bechara RI, Pelaez A, Palacio A, Joshi PC, Hart CM, Brown LA, Raynor R and Guidot DM: Angiotensin II mediates glutathione depletion, transforming growth factor-betal expression and epithelial barrier dysfunction in the alcoholic rat lung. Am J Physiol Lung Cell Mol Physiol 289: L363-L370, 2005.

8. Imai Y, Kuba K, Rao S, Huan Y, Guo F, Guan B, Yang P, Sarao R Wada T, Leong-Poi H, et al: Angiotensin-converting enzyme 2 protects from severe acute lung failure. Nature 436: 112-116, 2005.

9. Idell S, Kueppers F, Lippmann M, Rosen H, Niederman M and Fein A: Angiotensin converting enzyme in bronchoalveolar lavage in ARDS. Chest 91: 52-56, 1987.

10. Brasier AR, Recinos A III and Eledrisi MS: Vascular inflammation and the renin-angiotensin system. Arterioscler Thromb Vasc Biol 22: 1257-1266, 2002.

11. Masaki H, Kurihara T, Yamaki A, Inomata N, Nozawa Y, Mori Y, Murasawa S, Kizima K, Maruyama K, Horiuchi M, et al: Cardiac-specific overexpression of angiotensin II AT2 receptor causes attenuated response to AT1 receptor-mediated pressor and chronotropic effects. J Clin Invest 101: 527-535, 1998 .

12. Zhang $H$ and Sun GY: Expression and regulation of AT1 receptor in rat lung microvascular endothelial cell. J Surg Res 134: 190-197, 2006.

13. Garcia JG, Liu F, Verin AD, Birukova A, Dechert MA, Gerthoffer WT, Bamberg JR and English D: Sphingosine 1-phosphate promotes endothelial cell barrier integrity by Edg-dependent cytoskeletal rearrangement. J Clin Invest 108: 689-701, 2001.

14. Birukova AA, Wu T, Tian Y, Meliton A, Sarich N, Tian X, Leff A and Birukov KG: Iloprost improves endothelial barrier function in lipopolysaccharide-induced lung injury. Eur Respir J 41: 165-176, 2013.

15. Li H, Qiu H, Xu D, Liu L, Wang L, Dig H, Yang Y and Zhou S: Establishment of radioligand binding assay for angiotensin II type 1 receptor of human pulmonary microvascular endothelial cell after lipopolysaccharide stimulation. Int J Respir 27: 1761-1764, 2007.

16. Dincer HE, Gangopadhyay N, Wang R and Uhal BD: Norepinephrine induces alveolar epithelial apoptosis mediated by alpha-, beta- and angiotensin receptor activation. Am J Physiol Lung Cell Mol Physiol 281: L624-L630, 2001.

17. Li X, Shu R, Filippatos G and Uhal BD: Apoptosis in lung injury and remodeling. J Appl Physiol (1985) 97: 1535-1542, 2004.

18. Chan LY, Leung JC, Tang SC, Choy CB and Lai KN: Tubular expression of angiotensin II receptors and their regulation in $\mathrm{IgA}$ nephropathy. J Am Soc Nephrol 16: 2306-2317, 2005.

19. Li JY, Avallet O, Berthelon MC, Langlois D and Saez JM: Transcriptional and translational regulation of angiotensin II type 2 receptor by angiotensin II and growth factors. Endocrinology 140: 4988-4994, 1999.

20. Raiden S, Nahmod K, Nahmod V, Semeniuk G, Pereira Y, Alvarez C, Giordano M and Geffner JR: Nonpeptide antagonists of AT1 receptor for angiotensin II delay the onset of acute respiratory distress syndrome. J Pharmacol Exp Ther 303: 45-51, 2002.

21. Sasamura H, Nakazato Y, Hayashida T, Kitamura Y, Hayashi M and Saruta T: Regulation of vascular type 1 angiotensin receptors by cytokines. Hypertension 30: 35-41, 1997.

22. Li D, Yang B, Philips MI and Mehta JL: Proapoptotic effects of ANG II in human coronary artery endothelial cells: Role of AT1 receptor and PKC activation. Am J Physiol 276: H786-H792, 1999.

23. Trowbridge IS, Collawn JF and Hopkins CR: Signal-dependent membrane protein trafficking in the endocytic pathway. Annu Rev Cell Biol 9: 129-161, 1993.

24. Mukherjee S, Ghosh RN and Maxfield FR: Endocytosis. Physiol Rev 77: 759-803, 1997.

25. Marsh M and McMahon HT: The structural era of endocytosis Science 285: 215-220, 1999. 